\title{
RISK FACTORS FOR BEHAVIOURAL AND EMOTIONAL DISORDERS IN CHILDREN WITH MILD INTELLECTUAL DISABILITY
}

\author{
Katarina Tomic ${ }^{1}$, Goran Mihajlovic ${ }^{2}$, Slobodan Jankovic ${ }^{2}$, Nela Djonovic ${ }^{2}$, Natalija Jovanovic - Mihajlovic $^{3}$, Vladimir Diligenski ${ }^{4}$ \\ ${ }^{1}$ Vocational College for Preschool Teachers, Krusevac, Serbia \\ ${ }^{2}$ Medical Faculty, University of Kragujevac, Serbia \\ ${ }^{3}$ Department of Neurology, Clinical Centre Kragujevac \\ ${ }^{4}$ Department of Psychiatry, Clinical Centre "Dr Dragisa Misovic", Dedinje
}

\section{FAITORI RIZIIKA ZA BIHEJVIORALNE I EMOCIONALNE POREMEĆAJE KOD DECE SA LAKOM INTELEKTUALNOM OMETENOŠĆU \\ Katarina Tomić ${ }^{1}$, Goran Mihajlović ${ }^{2}$, Slobodan Janković ${ }^{2}$, Nela Đonović ${ }^{2}$, Natalija Jovanović - Mihajlović ${ }^{3}$, Vladimir Diligenski $^{4}$ ${ }^{1}$ Visoka škola strukovnih studija za obrazovanje vaspitača, Kruševac, Srbija \\ ${ }^{2}$ Medicinski fakultet, Univerzitet u Kragujevcu, Srbija \\ ${ }^{3}$ Odsek za neurologiju, Klinički centar Kragujevac \\ ${ }^{4}$ Klinika za psihijatriju, Kliničko-bolnički centar "Dr Dragiša Mišović", Dedinje}

Received / Primljen: 14. 03. 2012

Accepted / Prihvaćen: 21. 03. 2012.

\begin{abstract}
Introduction: The current study investigated the prevalence and characteristics of behavioural and emotional disorders in children with mild intellectual disability, as well as the predictive potential of personal and socio-demographic factors.
\end{abstract}

Objective: The main objective of this research was to determine the impact of socio-demographic and personal factors on the prevalence and types of emotional and behavioural disorders in children with mild intellectual disability.

Methods: Non-experimental research was conducted on 311 children with mild intellectual disability, aged 9-18 years, who attended 8 special primary schools in central and south-west Serbia. For the assessment of psychopathology, we used the Child Behaviour Checklist - Teacher Report Form (CBCL-TRF), a checklist of problem behaviours in children aged 6-18 years. To collect data on socio-demographic status, we created a questionnaire about socio-economic factors and demographic indicators. The informants were classroom teachers.

Results: An increased incidence of behavioural and emotional disorders was found in children with mild intellectual disability, compared to children of average intelligence. Both dimensions of psychopathology were significantly influenced by personal and socio-demographic variables, including child's age, gender, academic achievement, placement type, parental educational level and employment, as well as the structure and socio-economic status of the families.

Conclusion: Children with intellectual disability are at increased risk of developing psychopathology, mostly within the dimension of adjustment and behavioural disorders. Risk factors include specific developmental and psychological characteristics and social learning difficulties, as well as a number of adverse socio-demographic factors.

Keywords: intellectual disability, internalizing disorders, externalizing disorders.

\section{SAŽETAK}

Uvod: $U$ radu se razmatraju rasprostranjenost $i$ karakteristike bihejvioralnih $i$ emocionalnih poremećaja kod dece sa lakom intelektualnom ometenošću, kao i njihova veza sa personalnim i socio-demografskim činiocima kao potencijalnim faktorima rizika.

Cilj rada: Utvrditi uticaj socio-demografskih i personalnih faktora na rasprostranjenost $i$ vrste emocionalnih smetnji i poremećaja ponašanja kod dece sa lakom intelektualnom ometenošću.

Metod rada: Sistematsko neeksperimentalno istraživanje obavljeno je na uzorku od 311 dece sa lakom intelektualnom ometenošću, učenika 8 specijalnih osnovnih škola centralne i jugozapadne Srbije, starosti od 9-18 godina. Za procenu psihopatologije korišćena je Skala poremećaja u ponašanju i emocionalnih smetnji kod dece uzrasta 6-18 godina, CBCL - TRF (Child Behaviour Checklist - Teacher Report Form). Za prikupljanje podataka o socio-demografskom statusu korišćena je Skala socio-ekonomskih faktora i demografskih pokazatelja, konstruisana za potrebe ove studije. Informanti su bili nastavnici-razredne starešine.

Rezultati: Utvrđena je povećana učestalost emocionalnih i bihejvioralnih poremećaja kod dece sa lakim intelektualnim smetnjama u odnosu na decu prosečne inteligencije. Oba pola psihopatologije nalaze se pod značajnim uticajem ispitivanih personalnih $i$ socio-demografskih varijabli: uzrasta, pola, akademskog uspeha, vrste smeštaja deteta, nivoa obrazovanja $i$ zaposlenja roditelja, kao i strukture, brojnosti $i$ socio-ekonomskog statusa porodica.

Zaključak: Deca sa smetnjama u intelektualnom razvoju su pod pojačanim rizikom od ispoljavanja psihopatoloških fenomena, najčešće iz spektra problema ponašanja $i$ prilagodavanja, što je posledica specifičnih razvojno-psiholoških karakteristika, ali i poteškoća socijalnog učenja, kao i delovanja niza nepovoljnih socio-demografskih faktora.

Ključne reči: laka intelektualna ometenost, internalizovane smetnje, eksternalizovane smetnje.

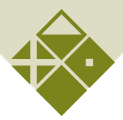

UDK: 159.922.76 / Ser J Exp Clin Res 2012; 13 (1): 19-24 DOI: 10.5937/SJECR13-1698 


\section{INTRODUCTION}

Intellectual disability (ID) refers to significant limitations in intellectual functioning and in social, conceptual and practical adaptive skills. Deficits must occur during the developmental period before the age of 18 and be measurable using standardized methods of assessment, based on internationally accepted classification criteria. The most commonly used practical classification criteria is the level of intellectual functioning. For example, persons whose intelligence quotient (IQ) levels are below the accepted limit of 70 are diagnosed as intellectually disabled $[1,2]$. Many studies have shown an increased incidence of psychiatric disorders in children and adolescents with ID compared to those without disability. Although research findings vary depending on how the study variables are operationalized, i.e., the characteristics of the assessment instruments used and the populations studied, estimates suggest that $30-60 \%$ of children and youth with ID suffer from certain types of psychiatric disorder; this rate is three to four times more frequent than in children of average intelligence [3, 4]. As many as $36.8 \%$ of children with mild ID meet the DSM-IV criteria for comorbid disorders, which seriously impedes their education, social integration and functioning and reduces their adaptive capacities [3]. The types and clinical characteristics of the disorders depend on the level of ID because it is clear that the expression of certain behavioural and emotional problems requires a certain level of intelligence [5]. As shown by many studies, in children and adolescents with mild ID, patterns of psychopathology are similar to those in the general population. For this reason, during the diagnostic and treatment planning processes, procedures and instruments designed for children and youth without disability can be used [6, 7]. Mental disorders in children with mild ID can be classified roughly into one of two dimensions: internalizing, which refers to strong internal control and symptoms that include withdrawal, dysphoria, anxiety and depression, and externalizing, which includes lack of internal control and tendencies toward excessive aggression, destructiveness, hyperactivity, and antisocial behaviours. These disorders tend to occur early in childhood and continue throughout development [8, 9]. The question arises as to which personal, social or developmental factors enhance the risk of psychopathology in children with mild ID compared to children of the general population. Of note, children with mild ID usually do not have any genetic or neurological disorders that would lead to greater probability of mental disorders [10]. For this reason, the impact of certain socio-demographic factors, educational environments and living conditions of children with mild ID should be the focus of attention. In this respect, results of different studies show that, during childhood, such children often come from poverty, social and emotional deprivation, a broken and dysfunctional family life, and their parents are mostly unemployed with low levels of education $[10,11]$.

\section{AIMS OF THE STUDY}

The main goal of this study was to identify the characteristics and prevalence of internalizing and externalizing disorders in children with mild ID. An additional goal was to examine the impact of certain personal and socio-demographic predictors as potential risk factors for the manifestation of psychopathology in this population of children.

\section{METHODS}

A systematic, non-experimental study was conducted on 311 students from 8 primary schools for Serbian children with mild ID. Participants were from 9-18 years old, with no comorbid conditions. We used a questionnaire that was designed for this study to assess socio-economic factors and demographic indicators, together with the Child Behaviour Checklist - Teacher Report Form (TRF), a scale for behaviour and emotional disorders in children aged 6-18 years [12]. The informants were classroom teachers. From the TRF, we used the Problem Scale, which consists of 113 problem behaviours that are scored as 0 (not true), 1 (somewhat or sometimes true) or 2 (completely or often true). The TRF provides a Total problem score, scores for Internalization and Externalization, as well as scores for several syndrome subscales, including anxious/depressed, withdrawn/depressed, somatic complaints, social problems, thought problems, attention problems, rule-breaking behaviour and aggressive behaviour. The first three subscales are part of the broader dimension of Internalization, the last two belong to the Externalization dimension, and the subscales of Social problems, Thought problems and Attention problems have similar saturation on both of the broader dimensions. Clinically significant scores for total problems and internalizing and externalizing dimensions were considered to be $\mathrm{T} \geq 63$, whereas clinical significance for syndrome subscales was set at $\mathrm{T} \geq 70$ [12].

The socio-economic factors and demographic indicators questionnaire that was used included the following variables: gender, age, IQ, academic achievement, grade repetition, occupation and educational level of parents, social assistance, birth order, as well as family structure and size.

\section{RESULTS}

The average age of participants in this study was 13.21 years $(\mathrm{SD}=2.24)$, and the average IQ was $62.18(\mathrm{SD}=6.81)$. The sample had more boys (58.8\%) than girls (41.2\%), but the gender distribution among age groups was balanced $(\mathrm{x} 2=4.678, \mathrm{df}=9, \mathrm{p}=0.861)$. The largest number of children $(60.8 \%)$ lived with both parents, more often in urban (79.7\%) than in rural areas (20.3\%). Only $31.5 \%$ of fathers and $9.3 \%$ of mothers were employed, and as many as $64.3 \%$ of families received some form of social assistance. As many as $60.8 \%$ of fathers and $74.5 \%$ of mothers had an in- 
Figure 1

* anx/d.: anxious/depressed, with/d.: withdrawn/depressed, somat.: somatic complaints, soc.pr.: social problems, tho.pr: thought problems, att. pr.: attention problems, rule b.b.: rule-breaking behaviour, aggress.: aggressive behaviour).

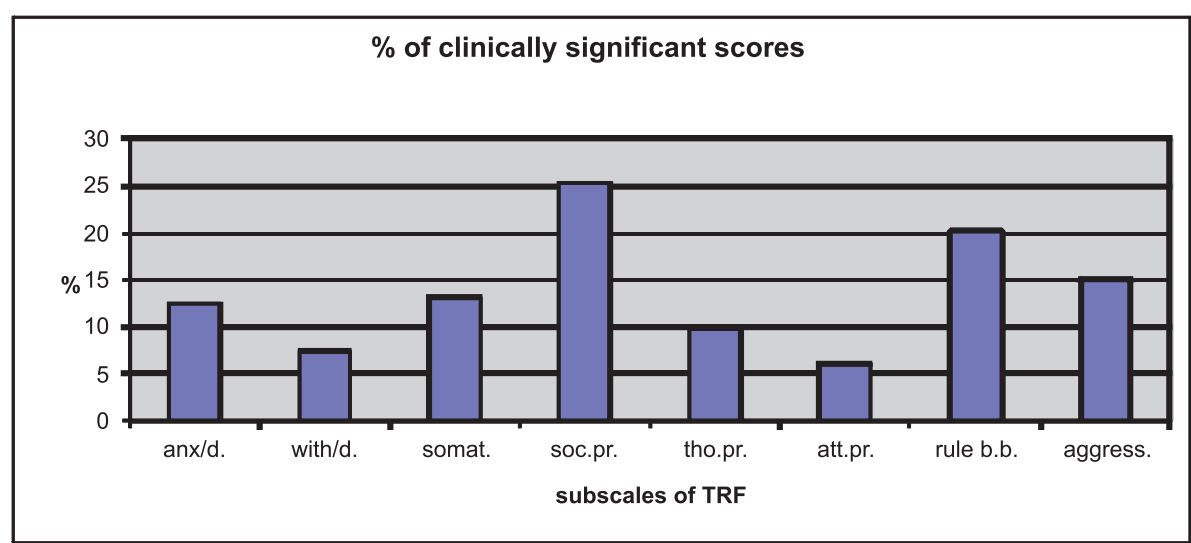

Figure 2

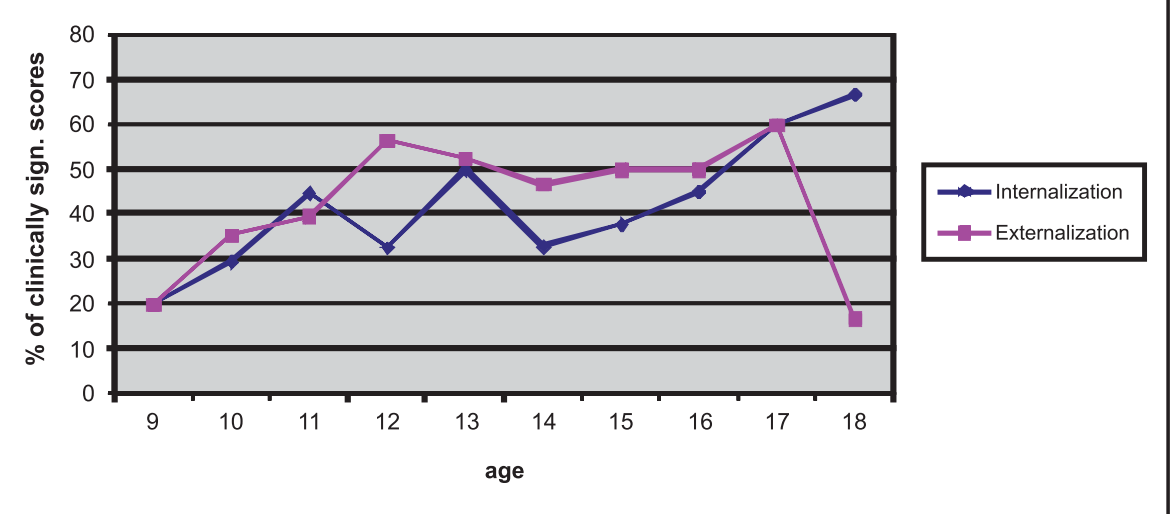

complete primary education, and only $3.2 \%$ of fathers and $3.9 \%$ of mothers had the highest levels of education (vocational college or university degree).

As many as 155 (49.8\%) children in our sample had a Total problem score in the clinical range, whereas 122 (39.2\%) had clinically significant Internalization scores and 145 (46.6\%) had clinically significant Externalization scores. On individual subscales, the highest frequencies of clinical scores were obtained on the subscales of Social problems (25.4\%) and Rule-breaking behaviour (20.26\%), whereas the lowest were on the subscales of Attention problems (6.11\%) and Withdrawn/depressed (7.40\%)(Figure 1). Statistically significant correlations were found between scores on broad-band dimensions of Internalization and Externalization and Social problems scores, with stronger relations between Internalization and Social problems $(\mathrm{r}=0,638, \mathrm{p}<0,0001)$ than between Externalization and Social problems $(\mathrm{r}=0,468, \mathrm{p}<0,0001)$. Low frequency of clinical scores for Attention problems was a surprising result, because it was expected that there would be more significant problems in this domain of functioning, considering the developmental and cognitive characteristics of the tested population. We clearly observed a slight dominance of externalizing disorders, particularly Rule-breaking behaviour, which was expected.

Girls had higher average scores on Total problems, Withdrawn/depressed and Attention problems ( $\mathrm{p}<0.0001$ ), whereas significant differences for other scores were not obtained. Age had a weak, but statistically significant, correlation with scores for Internalization $(r=0.160, p=$
0.005 ) and the subscales Anxious/depressed ( $\mathrm{r}=0.142, \mathrm{p}=$ 0.012 ) and Somatization $(\mathrm{r}=0.174, \mathrm{p}=0.002)$, but age was not correlated with the Externalization dimension. No statistically significant differences were found by comparing age groups on frequency of clinical scores for both broader dimensions ( $p>0.05)$. Frequencies of clinically significant scores in different age groups are shown in Figure 2.

In all age groups, except for ages 11 to 18, clinically significant scores of Externalization dominated over Internalization. Contrary to expectations, frequencies of clinical Externalizing problems did not decrease with age, but instead, these frequencies increased, except for a slight decrease in the participants aged 13 and 14 years, as well as a serious decrease at the age of 18 . The very low number of participants of that age (six) probably influenced this finding; notably, however, four of those six 18-year-old participants had clinically significant scores for Internalization, and only one for Externalization. Clinically significant behaviour problems, therefore, tended to be more pronounced with maturity, which was not expected. Clinical scores for Internalizing disorders showed consistent increase with the entry into early adolescence (age 14), which is consistent with previous studies.

Significant negative correlations were seen between IQ and Total problems $(\mathrm{r}=-0.158, \mathrm{p}=0.005)$, Internalization $(\mathrm{r}$ $=-0.330, \mathrm{p}<0.0001)$ and two of the subscales of that dimension, Anxious/depressed ( $\mathrm{r}=-0.346, \mathrm{p}<0.0005)$ and Withdrawn/depressed ( $\mathrm{r}=-0.302, \mathrm{p}<0.0005)$. IQ was positively correlated with Externalization $(\mathrm{r}=0.121, \mathrm{p}=0.033)$. Children with lower academic achievement had higher average 


\begin{tabular}{|l|l|l|l|l|l|l|l|}
\hline Independent variables & B & S.E. & Wald & df & Sig. & Exp (B) & 95\% CI for Exp (B) \\
\hline Gender (f) & 0,698 & 0,304 & 5,265 & 1 & 0,022 & $\mathbf{2 , 0 0 9}$ & $1,107-3,646$ \\
\hline School achievement & $-0,531$ & 0,145 & 13,354 & 1 & 0,0001 & $\mathbf{0 , 5 8 8}$ & $0,442-0,782$ \\
\hline Birth order & $-0,315$ & 0,134 & 5,521 & 1 & 0,019 & $\mathbf{0 , 7 3 0}$ & $0,561-0,949$ \\
\hline Father's education & 0,609 & 0,234 & 6,785 & 1 & 0,009 & $\mathbf{1 , 8 3 8}$ & $1,163-2,905$ \\
\hline Social assistance (not rec.) & 1,234 & 0,426 & 8,414 & 1 & 0,004 & $\mathbf{3 , 4 3 9}$ & $1,493-7,924$ \\
\hline
\end{tabular}

Table 1. Predictors of clinically significant scores of Internalization

\begin{tabular}{|l|c|c|c|c|c|c|c|}
\hline Independent variables & B & S.E. & Wald & df & Sig. & Exp (B) & 95\% CI for Exp (B) \\
\hline Intelligence quotient & 0,074 & 0,024 & 9,566 & 1 & 0,002 & $\mathbf{1 , 0 7 6}$ & $1,027-1,128$ \\
\hline Number of children & 0,374 & 0,176 & 4,539 & 1 & 0,033 & $\mathbf{1 , 4 5 4}$ & $1,030-2,050$ \\
\hline Number of adults & $-0,326$ & 0,154 & 4,469 & 1 & 0,035 & $\mathbf{0 , 7 2 2}$ & $0,534-0,977$ \\
\hline Residing in an orphanage & 1,949 & 0,783 & 6,205 & 1 & 0,013 & $\mathbf{7 , 0 2 4}$ & $1,515-32,651$ \\
\hline
\end{tabular}

Table 2. Predictors of clinically significant scores of Externalization

scores on all scales, except for the aggregate Externalization scale and the Aggression subscale, whereas children with higher achievement had higher average scores $(x 2=12.652$, $\mathrm{df}=4, \mathrm{p}=0.013$ ). Birth order was also significantly negatively correlated with the dimension of Internalization $(\mathrm{r}=-0.271$, $\mathrm{p}<0.0001$ ) and its subscales, Social problems and Thought and Attention problems, whereas no significant correlation with Externalization was observed. A total of 72 (59\%) of the children within the Clinically internalizing group $\left(\mathrm{N}_{\mathrm{i}}=122\right)$ were first-borns. Educational level and employment of parents were also significantly related to the problems of children, with higher scores on all scales in children whose parents had higher education levels, except for the subscale of Rule-breaking behaviour, where children whose parents had lower education also had higher scores $(\mathrm{x} 2=10.498, \mathrm{df}=3$, $\mathrm{p}=0.015$ ). Children of employed fathers had higher scores on all scales, except for Rule-breaking behaviour, whereas children of unemployed fathers had higher average scores $(\mathrm{Z}=-2.487, \mathrm{p}=0.013)$. Children of employed mothers had higher scores for Internalization, but no differences were found for the dimension of Externalization. Family size was connected to Internalizing problems, with scores on the dimension of Internalization and its subscales increasing with decreasing numbers of children in the family $(r=-0.230$, $p$ $<0.0001)$, and fewer family members in general $(r=-0.219$, $p$ $<0.0005)$. Scores for Externalization were significantly correlated only with the number of children in the family $(r=$ $0.134, \mathrm{p}=0.019$ ).

To develop a predictive model for clinical scores on the dimensions of Internalization and Externalization ( $\mathrm{T} \geq 63$ ), i.e., to identify the particular characteristics of a child and his or her family as well as broader social environmental factors that significantly influence maladaptation and emotional difficulties of tested children, we used the stepwise binary logistic regression method. Potential outcomes included the dichotomous dependent variables clinical internalization/ non-clinical internalization and clinical externalization/ non-clinical externalization. The analysis separated out the effects of several important factors. It was found that clinically significant Internalization was influenced by gender, school performance, birth order, father's educational level and social assistance for the family (Table 1), whereas clinical Externalization was affected by intelligence quotient, the number of adult household members, the number of children in the family and placement in an orphanage (Table 2). The risk for the manifestation of clinically significant Internalization was increased by female sex $(\mathrm{OR}=2.009)$, higher levels of education of the father $(\mathrm{OR}=1.838)$ and no social assistance from the state $(\mathrm{OR}=3.439)$, and this risk was reduced by better school achievement $(\mathrm{OR}=0.588)$ and later birth order $(\mathrm{OR}=0.730)$. Risk factors for clinical $E x$ ternalization were higher IQ ( $\mathrm{OR}=1.076)$, more children in the family $(\mathrm{OR}=1.454)$ and living in an orphanage $(\mathrm{OR}=$ 7.024), whereas the presence of more adult household members was a protective factor $(O R=0.722)$.

\section{DISCUSSION}

The results confirmed the hypothesis of a high prevalence of behavioural and emotional problems in children with mild ID. The obtained frequencies of clinically significant scores on the TRF scale were higher than expected; almost half of the sample (49.8\%) had clinically significant Total problems scores. Behavioural problems were more frequent than internalizing disorders, which was expected considering the age of the respondents $(70,4 \%$ were aged under 15 years) and the hypothesis that externalizing symptoms would be dominant in children with ID [13]. However, frequencies of clinically significant scores for behavioural problems remained stable in older children, too, which was slightly surprising, considering the expected decrease of externalizing symptoms with maturity. Similarly, a positive association was found between age and inter- 
nalizing disorders. Internalization scores increased with age, meaning that a larger share of emotional problems in adolescents was found, which is consistent with previous studies [14]. Polarization of problems into Internalization and Externalization dimensions may underestimate these children`s behavioural issues; our study highlighted the subscale of Social problems (24,5\% of clinical scores), suggesting that the items of that subscale could be more sensitive to the specific problems of this population, which include delayed development of social skills and poorer social relations $[5,12,15]$. Social problems are significantly related to emotional problems, especially depression, and also behavioural problems. Further research should place more emphasis on social skills in children with mild ID because it is clear that slower and impeded development of social skills and deficits of social cognition lead to considerable difficulties integrating into a social group and developing socially desirable behaviours, which can, in turn, result in pronounced maladaptation, aggression and internalizing problems. Surprisingly, girls had higher average scores for Attention problems, with no significant differences for broader dimensions of behaviour, in contrast to earlier findings that suggested more emotional and fewer behavioural problems in girls compared to boys [16]. A regression analysis did demonstrate a higher risk of emotional disorders in girls $(\mathrm{OR}=2,009)$, but no significant gender differences for behavioural problems were found, which was unexpected. Considering the psychopathological profile of girls established in this study, we could point to a change in the accepted paradigm of sexual diversity and hypothesize that girls are more vulnerable when it comes to certain types of disorders, especially behaviour problems and attention difficulties. Statistically significant relationships between other socio-demographic factors and emotional and behavioural problems in children were also confirmed, with special emphasis on such factors as the economic standard of the family, housing conditions and family size. Higher scores on screening scales were related to poor academic performance, low standard of living, residing in rural areas as well as higher education and employment of parents. Rule-breaking behaviour was an exception in that lower levels of education in parents and parental unemployment were associated with greater problems. Employment and higher education levels of parents were significantly correlated only with the Internalization dimension. This finding suggests the possibility in higher educated parents of higher emotional pressure, higher expectations when it comes to the child's development and more difficulty overall accepting the child`s disability. In addition, there may be a negative influence of parental business engagement and more frequent separations of the parents from their children. Children with better school achievement had higher average scores on the Externalization dimension. Together with the positive correlations found between IQ levels and Externalization scores, it could be concluded that intellectually and academically more successful children more often exhibit Ex- ternalizing problems. This finding is not consistent with previous findings, nor is it consistent with practical experience and common sense; it is simply hard to connect superior school performance and maladjusted behaviour.

Family size and birth order were negatively related to internalizing disorders, supporting the hypothesis of greater social pressure on first born and only children with ID. In addition, there could be a dampening effect of large families containing more adults, which provide more opportunities, therefore, for positive identification. Children living without mothers had higher scores on Internalization, whereas children without fathers had higher risk of Externalization, suggesting the diverse importance of parental figures in development, with fathers being more important in effecting behaviours consistent with social norms. As a variable, a larger number of children in the family related negatively to Externalization scores, possibly because of diminished opportunities for children's behaviour monitoring, which is a well-known risk factor for conduct disorders and maladjustment $[17,18]$. Moreover, residing in an orphanage significantly increased the risk of a behavioural disorder, which can again be explained by the lack of monitoring in these circumstances. In an orphanage, the typically disproportionate number of children to teachers causes reduced ability to establish close relationships and deeper emotional bonds, which are necessary for a child's positive identification and adoption of appropriate behaviour patterns. Other highly important questions include the consequences of early emotional deprivation, genetic-constitutional factors and potential abuse and neglect of children in foster care.

\section{CONCLUSION}

Children with mild ID are at increased risk for emotional and behavioural problems. Risk factors include developmental characteristics and specific socio-cultural and demographic factors, especially social deprivation, low standards of living, low parental education and employment, and changes in housing, family structure and size. More detailed research is needed considering the impact of certain socio-demographic factors on the mental health of these children. Such research could lead to better opportunities for prevention and early detection of risk factors that may lead to the manifestation of clinically significant emotional and behavioural disorders.

\section{ACKNOWLEDGMENTS}

The authors would like to express their gratitude to the Ministry of Education and Science of the Republic of Serbia for Grant $N^{\circ} 175013$ and to The Medical Faculty of the University of Kragujevac for Junior Internal Research Grant $\mathrm{N}^{\circ}$ 14/10, from which the clinical trials that served as the basis for this Solicited Review were jointly funded. 


\section{REFERENCES}

1. American Psychiatric Association. Diagnostic and statistical manual of mental disorders $4^{\text {th }}$ ed. Washington DC: American Psychiatric Association; 1994.

2. Svetska zdravstvena organizacija. ICD-10 Klasifikacija mentalnih poremećaja i poremećaja ponašanja klinički opisi i dijagnostička uputstva. Beograd: Zavod za udžbenike i nastavna sredstva; 1992.

3. Dekker MC, Koot HM, Van der Ende J, Verhulst FC. (2002): Emotional and behavioral problems in children and adolescents with and without intellectual disability. J Child Psychol Psychiatry 2002; 43: 1087-98.

4. Linna SL et al. Psychiatric symptoms in children with intellectual disability. Eur Child Adolesc Psychiatry 1999; 8:77-82

5. Borthwick-Duffy SA, Lane KL,Widaman KF. Measuring problem behaviors in children with mental retardation: $\mathrm{Di}$ mensions and predictors. Res Dev Disabil 1997; 18: 415-33.

6. Dykens EM. Annotation: Psychopathology in children with intellectual disability. J Child Psychol Psychiatry 2000; 41: 407-17.

7. Einfeld SL, Tonge BJ. Population prevalence of psychopathology in children and adolescents with intellectual disability: II Epidemiological findings. J Intellect Disabil Res 1996; 40: 99-109.

8. Baker BL, Blacher J, Crnic KA, Edelbrock C. Behavior Problems and Parenting Stress in Families of ThreeYear-Old Children With and Without Developmental Delays. Am J Ment Retard 2002; 107: 433-44.

9. Tonge BJ, Einfeld SL. The trajectory of psychiatric disorders in young people with intellectual disabilities. Aust N Z J Psychiatry 2000; 34: 80-4.

10. Wallander JL, Dekker MC, Koot HM. Risk factors for psychopathology in children with intellectual disability: a prospective longitudinal population-based study. J Intellect Disabil Res 2006; 50: 259-68.
11. Emerson E, Hatton C. Poverty, Socio economic Position, Social capital and the health of children and adolescents with intellectual disabilities In Britain: a replication. J Intellect Disabil Res 2007; 51(11): 866-74.

12. Achenbach TM, Rescorla LA. Manual for the ASEBA School-Age Forms \& Profiles. Burlington, VT: University of Vermont, Research Center for Children, Youth, \& Families; 2001.

13. Crnic K, Hoffman C, Gaze C, Edelbrook C. Understanding the Emergence of Behavior Problems in Young Children With Developmental Delays. Infants and Young Children 2004; 17: 223-35.

14. Overbeek G, Vollenberg W, Meeus W, Engels R, Luijpers E. Course, Co-Occurrence, and Longitudinal Associations of Emotional Disturbance and Delinquency From Adolescence to Young Adulthood: A Six-Year Three-Wave Study. J Youth Adolesc 2001; 30: 401-26.

15. Brojčin B, Banković S, Japundža-Milisavljević M. Socijalneveštine dece i mladih s intelektualnom ometenošću, Nastava i vaspitanje 2011; 3: 419-29.

16. Dekker M, Koot HM. DSM-IV Disorders in Children With Borderline to Moderate Intellectual Disability. II: Child and Family Predictors. J Am Acad Child Adolesc Psychiatry 2003; 42: 923-31.

17. Ramsden SR, Hubbard JA. Family Expressiveness and Parental Emotion Coaching, J Abnorm Child Psychol 2002; 30: 657-67.

18. Capaldi DM, Eddy MJ. Oppositional Defiant Disorder and Conduct Disorder. U: Gullota TP, Adams GR, urednici. Handbook of Adolescent Behavioral Problems - Evidence based Approaches to Prevention and Treatment. Springer Science and Business Media, New York; 2005. p. 283-308. 